\title{
Gender Differences in Stress Perception among Special Education Students
}

\author{
Michael Eskay ${ }^{1}$, Florence Ijeoma Arumede ${ }^{1}$, Annastasia Uchenna Eneh ${ }^{1} \&$ Jane Ogoma Aja ${ }^{1}$ \\ ${ }^{1}$ Department of Educational Foundations, University of Nigeria, Nsukka, Enugu State, Nigeria \\ Correspondence: Florence Ijeoma Arumede, Department of Educational Foundations, University of Nigeria, \\ Nsukka. E-mail: florence.arumede@unn.edu.ng
}

Received: October 15, 2019 Accepted: December 6, 2019 Online Published: December 12, 2019

doi:10.5539/gjhs.v11n14p115 URL: https://doi.org/10.5539/gjhs.v11n14p115

\begin{abstract}
This study examined gender differences in stress perception among special education students in South-East Nigerian Universities. One research question and a null hypothesis guided the study. The study design was a descriptive survey. The study sampled 800 students enrolled in special education. The instrument for collection of data was a questionnaire which measures the perception of stress in students. The research data were analyzed using mean, standard deviation and t-test. The finding of the study revealed that there was no significant between male and female academic stress. For affected students of special education to be stress-free, the collaboration of special education experts and educational stakeholders is necessary for assisting such students.
\end{abstract}

Keywords: gender, stress perception, special education, students

\section{Introduction}

The feelings or thoughts that a person has regarding the amount of stress they are experiencing at a certain point in time or over a given period is known as perceived stress (Cohen, Kamarck, \& Mermelstein, 1983; Lazarus, \& Folkman, 1984; Phillips, 2013). Students of special education could be affected by how much they perceive stress as they try to cope with school and daily life tasks. Nweze (2005) stated that everybody is affected by stress as a result of environmental demands. Kyriacou and Sutcliffe (1978) were of the view that stress has a negative influence on the student which predisposes them to less academic achievement.

Special education ensures that people with special needs are empowered educationally, socially, and psychologically (Omede, 2016). Florian (2008) observed that the introduction of special education into the educational system has helped to remove learning barriers for special need students. UNESCO (1999) opined that special education should address discriminations. The Universal Basic Education (UBE) Act of 2004 and the National Policy on Education (NPE) was proposed with the interest of equalizing education for all regardless of mental, emotional, sensory and social challenges (FRN, 2013). Agunloye, Pollingue, Davou, and Osagie (2011) stated that special need students are taught better when they are assigned to teachers of special education for intensive teaching.

Stress level by gender is an important area of research. Gender is the personal sexual identification of an individual, regardless of the person's biological and outward sex. Kendra (2004) reported that gender tries to differentiate masculinity (male) from feminity (female) from cultural and background assumption in differentiating societal expectation which is established by individual behavioural, emotional and physical attributes that are related to male and female. Cassel (2002) saw gender as the social fact of being male or female. Gender according to Long (2013) is the behavioural differences between males and females that are culturally-based and socially learned. Gender is the range of trait relating to, and differentiating between male and female social roles (Hazel \& Sally, 2000).

According to Gada (2002), stress is defined as any specific response of the body to all demands made on it. For Mgbodile (2004), stress refers to the internal or external condition or situation that imposes a demand for adjustment on the individual. Abanobi (2005) noted that stress is the pressure or worry resulting from problems people encounter in their daily living. Oboegbulem (1995) asserted that moderate stress stimulates a person to act well in adjusting effectively to constant changes in the world. Oboegbulem, buttressing further noted that positive results of stress on individual serves as a force stimulation in their career as it encourages them to aim higher in 
their career. However, Okere and Onyechi (2007) stated that adverse stress brings confusion to students in their learning environment. Dierendonck and Visser (2005) observed that individual's ability fall below expectation because of stress. Dierendonck and Visser noted that stress reduces the functional abilities of individuals. Dierendonck and Visser further stated that people could become depressive, sad, angered among others because of stress. There is a dearth of evidence regarding stress perception among special education students. The purpose of this study was to ascertain gender differences in stress perception among special education students in South-East Nigerian Universities.

\section{1 research question}

1) Is there a gender difference in stress perception among special education students?

\subsection{Hypothesis}

The hypothesis below was raised and tested at 0.05 probability level.

1) There is no significant difference in stress perception among male and female special education students.

\section{Research Method}

The study design was a descriptive survey conducted over the course of three months in 2018 . The study targeted all the universities in South-East Nigeria. The study used a convenience sample of 800 students enrolled in special education. All participating students of special education provided informed consent. The instrument for data collection was researchers-developed questionnaire titled "Students Stress Perception Questionnaire" (SSPQ). It is structured on a four-point rating scale of Strongly Agreed (SA) to Strongly Disagreed (SD). The instrument was face-validated by experts. The internal consistency of the instrument was determined using Cronbach alpha $(0.87 \alpha)$. The instrument was administered directly to the respondents by the researchers with the help of three assistants. Mean and standard deviation was used in answering the research question while t-test was used on hypothesis.

\section{Results}

Research Question: Is there a gender difference in stress perception among special education students?

Table 1. Mean difference in stress perception among special education students by gender

\begin{tabular}{lccc}
\hline Gender & $\mathrm{N}$ & Mean & Std. Deviation \\
\hline Male & 381 & 25.83 & 6.44 \\
Female & 419 & 28.08 & 5.87 \\
\hline
\end{tabular}

Result in Table 1 revealed that male special education students had a mean stress of 25.83 with a standard deviation of 6.44 while female special education students had mean stress of 28.08 with a standard deviation of 5.87. These mean scores suggest that male students enrolled in special education experience less stress than their female counterparts.

\section{Hypothesis}

There is no significant difference in stress perception among male and female special education students.

Table 2. Independent samples t-test of mean difference in stress perception among special education students

\begin{tabular}{cccccccc}
\hline Gender & $\mathrm{N}$ & $\mathrm{M} \pm \mathrm{SD}$ & $\mathrm{t}$ & $\mathrm{df}$ & Sig. & Mean Difference & $95 \% \mathrm{CI}$ \\
\hline Male & 381 & $25.83 \pm 6.44$ & & & & & \\
Female & 419 & $28.08 \pm 5.87$ & -5.169 & 798 & .000 & -2.24912 & $-3.103,-1.395$ \\
\hline
\end{tabular}

$\mathrm{M} \pm \mathrm{SD}=$ Mean, Standard Deviation; N=Number of Respondents, $\mathrm{CI}=$ Confidence Interval.

Result in Table 2 showed that there is a statistically significant difference in stress perception among male and female students of special education in Nigerian universities, $t(798)=-5.169, \mathrm{p}=.000,95 \% \mathrm{CI}=-3.103,-1.395$. Female students had a high level of perceived stress compared to their male counterparts. 


\section{Discussion}

The present study showed that there is a statistically significant difference in stress perception among male and female students of special education in South-East Nigerian universities. Specifically, female students had a high level of perceived stress compared to their male counterparts. Nnabuihe, Onyeizugbe and Onwuka (2012) showed that stress is likely to be profound among females than their male counterparts. Nwefuru et al. (2018) reported that undergraduate students experience academic stress at a high level. Nwokenna et al. (2019a) reported that there exists stress among students. Ogbueghu et al. (2019) reported no gender differences in perceived stress among undergraduate students of Economics Education. Nwokenna et al. (2019b) also revealed that undergraduate students experience stress in their effort to overcome academic challenges confronting them. Al-Omar (2003) reported that stress may affect all individuals irrespective of gender. However, Liu and Zhu (2009) reported that men are likely to experience more stress than women.

Shaikh, Kahloon, and Kazmi (2004) reported that students experience academic stress because of overloaded take-home assignments they been assigned to. Erkutlu and Chafra (2006) reported that students stress can be associated with family engagement, socio-personal and failure to achieve positively on academics. Talib and Zai-urRehman (2012) reported that students at all level in tertiary institutions experience stress in different dimension which invariably affects their academic grade. Mani (2010) revealed that students experience stress in their attempts to adjust for any academic examination. Baldwin, Wilkinson, and Bradley (2009) reported that students experience stress both within and outside the school environment. Smith and Renk (2007) reported that small classroom for teaching and learning and academic failure are agents of students' academic stress. For affected students of special education to be stress-free, the collaboration of special education experts and educational stakeholders is necessary for assisting such students.

\section{Conclusion}

Male students enrolled in special education course experience less stress than their female counterparts. Thus, there is a statistically significant difference in stress perception among male and female students of special education in South-East Nigerian universities. Therefore, special education experts through governmental and nongovernmental aids should initiate interventions for reducing stress amongst female special education students.

\section{References}

Baldwin, D. A., Wilkinson, F. C., \& Barkley, D. C. (2009). Effective management of student employment: Organizing for standard deployment in academic libraries. Englewood: Libraries Unlimited, Inc.

Cohen, S., Kamarck, T., \& Mermelstein, R. (1983). A global measure of perceived stress. Journal of Health and Social Behavior, 24, 385-396.

Erkutlu, H. V., \& Chatra, J. (2006). Relationship between leadership power bases and job stress of subordinates: Example from boutique hotels. Management Resources News, 29(5), 285-297.

Federal Republic of Nigeria (FRN). (2013). National Policy on Education. Lagos: NERDC Press.

Florian, L. (2008). Inclusion: Special or inclusive education: Future trends. British Journal of Special Education, 35(4), 202-208. https://doi.org/10.1111/j.1467-8578.2008.00402.x

Lazarus, R. S., \& Folkman, S. (1984). Stress, coping and adaptation. New York: Springer.

Mani, V. (2010). Students' perception of the impact of coursework on exam stress. Uganda International Journal of Arts and Sciences, (3), 104-110.

Nwefuru, B. C., Otu, M. S., Eseadi, C., Usen, S. A., \& Otu, F. M. (2018). Stress, Depression, Burnout and Anxiety among Chemistry Education Students in Universities in South-East, Nigeria. Journal of Consultancy, Training \& Services, 2(2), 46-54.

Nwokenna, E. N., Aneke, A. O., Ossai, O. V., \& Nwefuru, B. C. (2019a). Internet-Guided Music Intervention for Stress among University Students. Journal of Engineering and Applied Sciences, 14(4SI), 7400-7403. https://doi.org/10.36478/jeasci.2019.7396.7399

Nwokenna, E. N., Nwosu, N., Igbokwe, U. L., Victor-Aigbodion, V., Nnamani, O., \& Nwefuru, B. C. (2019b). Music Intervention for Perceived Stress among English Education Students. Global Journal of Health Science, 11(8), 23-28. https://doi.org/10.5539/gjhs.v11n8p23

Oboegbulem, A. (1995). Stressors and Stress Management Strategies of Teachers and Principals of Enugu and Anambra States of Nigeria. Unpublished Ph.D. Thesis, University of Nigeria, Nsukka. 
Ogbueghu, S. N., Aroh, P. N., Igwe, R. A., Dauda, J. E., Eze, D. M., Opara, I. E., Nwefuru, B. C., \& Eneogu, N. D. (2019). Gender differences in perceived stress among Economics Education undergraduate students in South-East, Nigeria. Global Journal of Health Science, 11(14), 46-51. https://doi.org/10.5539/gjhs.v11n14p46

Okere, A., \& Onyechi, K. C. (2007). Counseling for Stress Management: A University of Nigeria Students Health, Promotion for attainment of Millennium Development Goals. A paper presented at the annual conference of the Faculty of Education, University of Nigeria, Nsukka, 6-11 ${ }^{\text {th }}$ August.

Omede, A. A. (2016). Policy Framework on Inclusive Education in Nigeria: Issues and Challenges. Public Policy and Administration Research, 6(5), 33-38.

Phillips, A. C. (2013). Perceived Stress. In M. D. Gellman, \& J. R.Turner (Eds.), Encyclopedia of Behavioral Medicine. Springer, New York, NY

Shaikh, B. T., Kahloon, A., \& Kazmi, M. (2004). Students stress and coping strategies: A case of Pakistani medical school. Education for Health, 17, 346-353. https://doi.org/10.1080/13576280400002585

Smith, A., \& Renk, O. A. (2007). Predictors of academic-related stress in college students: an examination of coping, social support, parenting and anxiety. Journal of National Association of Student Personnel Administrators (NASPA), 44, 405-431. https://doi.org/10.2202/0027-6014.1829

Talib, N., \& Zair-ur-Rehman, M. (2012). Academic performance and perceived stress among University students. Educational Research Review, (7), 127-132. https://doi.org/10.5897/ERR10.192

UNESCO. (1999). World declaration on education for all and framework of action to meet basic learning needs. Adopted by the World Conference on Education For All, Jomtien, Thailand, 5-6th March. Retrieved from http://www.unesco.org/education/PDF/ JOMITIE_E.PDF

\section{Copyrights}

Copyright for this article is retained by the author(s), with first publication rights granted to the journal.

This is an open-access article distributed under the terms and conditions of the Creative Commons Attribution license (http://creativecommons.org/licenses/by/4.0/). 